\title{
Differential induction of heat shock mRNA in oligodendrocytes, microglia, and astrocytes following hyperthermia
}

\author{
Jane A. Foster, Ian R. Brown * \\ Department of Zoology, University of Toronto, Scarborough Campus, 1265 Military Trail, West Hill, Ont. M1C 1A4, Canada
}

Accepted 21 May 1996

\begin{abstract}
A time course analysis of hsp70 mRNA induction in response to a physiologically relevant increase in body temperature of $2.6^{\circ} \mathrm{C}$ was performed in the rabbit forebrain. A protocol that combined in situ hybridization and cytochemistry on the same tissue section was employed to identify reactive glial cell types. Cytochemical markers for astrocytes, microglia, and oligodendrocytes were utilized in combination with a DIG-labelled hsp70 riboprobe, which permitted mRNA localization at high resolution. Four glial cell body-enriched regions of the rabbit forebrain were examined, namely, cortical layer 1, hippocampal fissure, corpus callosum, and fimbria. Maximal hsp70 mRNA induction was observed in 2 and $3 \mathrm{~h}$ hyperthermic animals. The colocalization analysis demonstrated that hsp70 mRNA was induced in oligodendrocytes and microglia, but not in forebrain GFAP positive astrocytes. In addition, cell counts were performed which showed that almost all oligodendrocytes induced hsp70 mRNA while a subpopulation of microglial cells responded. These data are consistent with the notion that oligodendrocytes, microglia, and astrocytes exhibit distinct thresholds for activation of the heat shock response following a physiologically relevant increase in body temperature.
\end{abstract}

Keywords: Hsp70; Hsc70; Stress protein; Hybridization, in situ

\section{Introduction}

The mammalian hsp70 multigene family is comprised of constitutive and stress-inducible members [23,56]. Constitutively expressed members function as molecular chaperones and are involved in protein folding, transport, and translocation [3,15-17,57]. Hsc70 is expressed at high levels in unstressed cells [46]. In the mammalian central nervous system (CNS), constitutive hsc70 mRNA is found at abundant levels in forebrain neurons [12], cerebellar Purkinje neurons [26], brain stem neurons [13], and spinal cord motor neurons [27]. Hsp70 is strongly induced following neural traumas including hyperthermia, ischemia, and wounding (for review see $[4,5,36]$ ). In global ischemia studies [7,34,45,54] and focal ischemia studies [20,58], neurons respond by inducing stress-inducible hsp70 mRNA and protein. Following a fever-like increase in body temperature, a strong glial induction has been reported (reviewed by [5]).

Several studies have suggested a protective role for hsp70 protein following cellular stress $[9,37,38]$. Using

\footnotetext{
${ }^{*}$ Corresponding author. Fax: + 1 (416) 287-7642.
}

mammalian non-neural cells grown in tissue culture, it has been shown that impairment of hsp70 induction leads to thermosensitive cells $[18,40]$, and that prior heat treatment can confer thermotolerance $[1,22,49]$. Several experiments at the in vitro level have suggested a protective role for hsp70 in the mammalian nervous system. Injecting antihsp70 antibodies into cultured neurons resulted in increased sensitivity to heating [19] and transfection of the stress-inducible hsp70 gene into cultured rat neurons and glia conferred protection from heat stress [52]. Tissue culture studies have also shown that prior heat shock can have neuroprotective effects against subsequent insults $[21,24,41]$. In vivo demonstrations of protective effects have been reported. Prior whole body hyperthermia resulted in protection against bright light degeneration of photoreceptors in the rat retina [2]. In rat forebrain, prior hyperthermia protected neurons from ischemic damage [6].

Previous work in our laboratory has revealed a strong glial induction following hyperthermia in rabbit cerebellum, brain stem, spinal cord, and forebrain [13,25-28,48]. Other groups, working both in vitro and in vivo, have demonstrated a glial induction of hsp70 in response to temperature elevation in rat [29,31-33], mouse [43], and 
human $[10,14,42]$. In the present investigation, we have sought to identify which glial cell types induce hsp70 mRNA in the rabbit forebrain in response to physiologically relevant hyperthermia. A method was employed which combines non-radioactive (digoxigenin; DIG) in situ hybridization and cytochemistry to identify astrocytes, microglia, and oligodendrocytes in the rabbit forebrain. This procedure permitted colocalization of hsp70 mRNA and cell type markers in the same cell. Anti-glial fibrillary acidic protein (GFAP) was used as an astrocyte marker. Microglia were identified using the lectin GSA I-B I $_{4}$ from Griffonia simplicifolia [50] and oligodendrocytes were identified using the lectin GSL II from G. simplicifolia [51]. The time course of the glial response to hyperthermia was examined in forebrain regions that are enriched in glial cell bodies, namely, cortical layer I, hippocampal fissure, corpus callosum, and fimbria.

\section{Materials and methods}

\subsection{Treatment of animals}

The body temperature of adult male New Zealand white rabbits (mean weight $=1.9 \mathrm{~kg}$ ) was elevated $2.6^{\circ} \mathrm{C}$ above normal $\left(39.6^{\circ} \mathrm{C}\right)$ by the intravenous injection of LSD at $100 \mu \mathrm{g} / \mathrm{kg}$ as previously described [8]. We have previously shown that the induction of hsp70 mRNA in the rabbit brain is due to the hyperthermic effects of the drug [25]. The core body temperature of the animals was monitored, with a rectal thermistor probe, prior to injection, at 15 min intervals for $90 \mathrm{~min}$, and at hourly intervals for up to $5 \mathrm{~h}$ following LSD injection. Core body temperature reached a maximum at $1 \mathrm{~h}$ and returned to normal by $4 \mathrm{~h}$ (Fig. 1). Animals were killed at 1, 2, 3, 5, and $10 \mathrm{~h}$ post-LSD injection. Animals were anesthetized with pentobarbital $(80 \mathrm{mg} / \mathrm{kg})$ injected via the marginal ear vein. Brains were removed, frozen in OCT embedding compound and stored at $-70^{\circ} \mathrm{C}$ until use.

\subsection{Synthesis of riboprobes}

The subclone $\mathrm{pH} 2.3$, a $2.3 \mathrm{~kb}$ HindIII-BamHI fragment of the human hsp70 inducible gene in pGEM1, was obtained from R. Morimoto [59]. An 843 bp insert was digested out with $\mathrm{ClaI}$ and HindIII and subcloned into the vector pBluescript KS for preparation of hsp70 riboprobes.

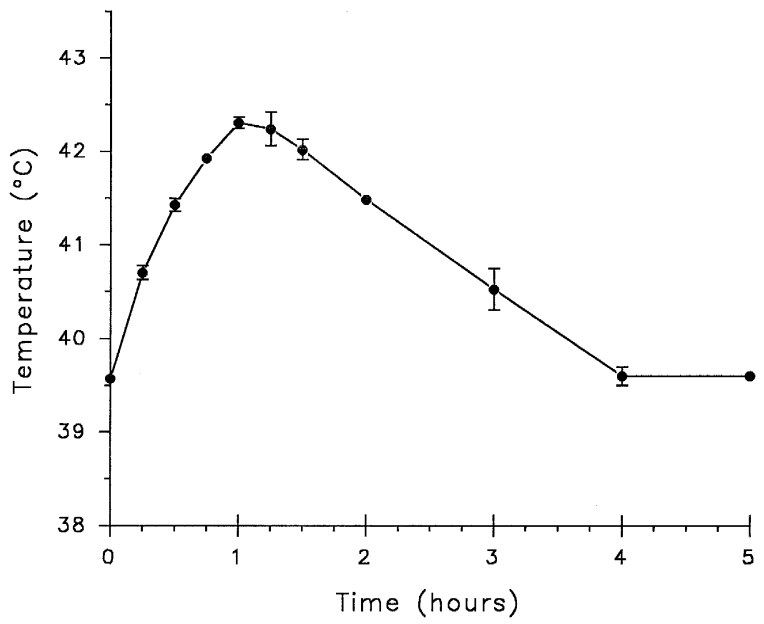

Fig. 1. Temperature increase following drug-induced hyperthermia. The body temperature of adult male New Zealand white rabbits was elevated $2.6^{\circ} \mathrm{C}$ above normal $\left(39.6^{\circ} \mathrm{C}\right)$ by the intravenous injection of LSD at 100 $\mu \mathrm{g} / \mathrm{kg}$. Body temperature was monitored with a rectal thermistor probe, prior to injection, at $15 \mathrm{~min}$ intervals for $90 \mathrm{~min}$ and at $1 \mathrm{~h}$ intervals for up to $5 \mathrm{~h}$. Core body temperature reached a maximum at $1 \mathrm{~h}$ and returned to normal by $4 \mathrm{~h}$. The data shown represent temperatures recorded for a total of 18 animals, 3 control animals and 3 animals per hyperthermic treatment. Hyperthermic animals were killed at 1, 2, 3, 5, and $10 \mathrm{~h}$ post-LSD injection.

Linearization with $\mathrm{ClaI}$ or HindIII and subsequent in vitro transcription incorporating ${ }^{35} \mathrm{~S}$ - or digoxigenin-labelled UTP using T7 and T3 polymerases produced antisense and sense hsp70 riboprobes, respectively.

The subclone pHA 7.6, a $600 \mathrm{bp}$ EcoRI fragment from the human constitutive hsc70 related protein $\mathrm{p} 70$ in pGEM1, was obtained from R. Morimoto [55]. The $600 \mathrm{bp}$ EcoRI fragment was digested out and subcloned into the vector pBluescript KS for preparation of hsc70 riboprobes. Production of antisense and sense hsc70 riboprobes was achieved by linearization with HindIII or BamHI, followed by in vitro transcription incorporating ${ }^{35} \mathrm{~S}$ - or digoxigenin-labelled UTP by T7 and T3 polymerases, respectively.

\subsection{Pretreatment of sections}

A series of $12 \mu \mathrm{m}$ frozen sections were thaw mounted on gelatin-coated glass slides ( $1 \%$ gelatin, $0.5 \%$ chromium potassium sulfate) and air dried. Tissue sections were fixed in $4 \%$ formalin (4\% formaldehyde in phosphate buffered

Fig. 2. Expression pattern of hsc70 mRNA and hsp70 mRNA in control and hyperthermic rabbit forebrain. Tissue sections from control and hyperthermic $(1,2,3,5,10 \mathrm{~h})$ rabbits were hybridized with either ${ }^{35}$ S-labelled hsc70 riboprobe (A) or hsp70 riboprobe (B). Constitutive hsc70 mRNA was detected in neuron-enriched regions including cortical layers (CL), hippocampus (HP), and thalamus (THA) in control (CON) rabbit forebrain. Left panels show that the pattern of hsc70 mRNA expression did not differ following hyperthermia. Basal expression of hsp70 mRNA was observed in cortical layers, hippocampus, and thalamus (B-CON). Following hyperthermia, an induction of hsp70 mRNA was observed in fiber tract regions, including corpus callosum (CC) and fimbria (F). The response was maximal at 2 and $3 \mathrm{~h}$ (B-2 HR, $3 \mathrm{HR}$ ), reduced at $5 \mathrm{~h}$ (B-5 HR) and returned to basal levels by $10 \mathrm{~h}$ (B-10 HR). The intense hybridization signal at 2 and $3 \mathrm{~h}$ reflected very high levels of hsp70 mRNA expression at these time points. Bar $=4 \mathrm{~mm}$. 

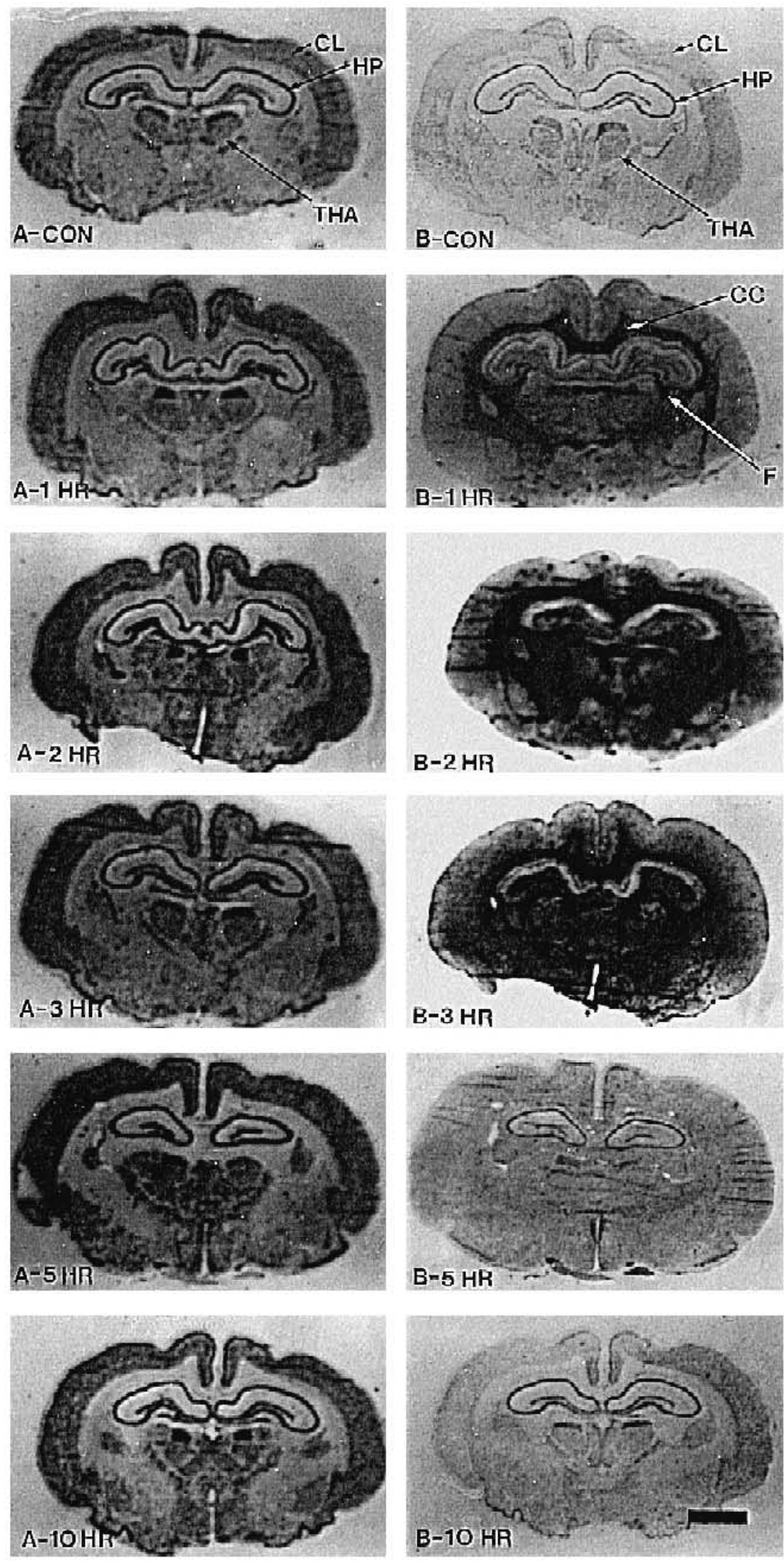
saline) for $5 \mathrm{~min}$, rinsed for $2 \mathrm{~min}$ in $2 \times \mathrm{SSC}(0.3 \mathrm{M}$ sodium chloride, $0.03 \mathrm{M}$ sodium citrate, $\mathrm{pH}$ 7.0), incubated for $10 \mathrm{~min}$ in $\mathrm{TEA} / \mathrm{NaCl} / \mathrm{AA}(0.1 \mathrm{M}$ triethanolamine, $0.9 \%$ sodium chloride, $0.5 \%$ acetic anhydride) and rinsed in $2 \times \mathrm{SSC}$. Slides were dehydrated in increasing alcohol concentrations, incubated in chloroform for $5 \mathrm{~min}$, to delipidate tissue, followed by $1 \mathrm{~min}$ in absolute alcohol, $1 \mathrm{~min}$ in 95\% alcohol, and air dried [39].

\subsection{Radioactive in situ hybridization}

Tissue sections were hybridized for $5 \mathrm{~h}$ at $55^{\circ} \mathrm{C}$, with $100 \mu$ l of hybridization buffer (50\% formamide, $10 \%$ dextran sulfate, $0.02 \%$ Ficoll, $0.02 \%$ polyvinylpyrrolidone, $0.02 \%$ bovine serum albumin, $50 \mathrm{mM}$ dithiothreitol, 0.5 $\mathrm{mg} / \mathrm{ml}$ yeast tRNA, $0.64 \mathrm{mg} / \mathrm{ml}$ herring testis DNA and $0.1 \mathrm{mM}$ sodium acetate, $750 \mathrm{mM} \mathrm{NaCl}, 75 \mathrm{mM}$ sodium citrate, $\mathrm{pH} 7.0$ ), containing $2 \times 10^{6} \mathrm{cpm}$ of one of the ${ }^{35}$ S-UTP labelled riboprobes: hsc70 antisense or sense, hsp70 antisense or sense. Slides were rinsed in Tris $/ \mathrm{NaCl}$ buffer $(500 \mathrm{mM} \mathrm{NaCl}, 1 \mathrm{mM}$ EDTA, $10 \mathrm{mM}$ Tris, $\mathrm{pH}$ 8.0 ), incubated for $30 \mathrm{~min}$ in RNase buffer $(500 \mathrm{mM} \mathrm{NaCl}$, $1 \mathrm{mM}$ EDTA, $10 \mathrm{mM}$ Tris, $\mathrm{pH} 7.5)$ containing $20 \mu \mathrm{g} / \mathrm{ml}$ RNase A, and washed for $1 \mathrm{~h}$ at $37^{\circ} \mathrm{C}$ in RNase buffer containing $0.3 \mathrm{M} \beta$-mercaptoethanol followed by $1 \mathrm{~h}$ wash at $70^{\circ} \mathrm{C}$ in $0.1 \times \mathrm{SSC}, 0.3 \mathrm{M} \beta$-mercaptoethanol. The slides were dehydrated through an alcohol series containing $0.33 \mathrm{M}$ ammonium acetate, air dried and set up with autoradiographic X-ray film.

\subsection{Non-radioactive in situ hybridization}

Tissue sections were hybridized for $5 \mathrm{~h}$ at $55^{\circ} \mathrm{C}$, with $100 \mu \mathrm{l}$ of hybridization buffer containing approximately $500 \mathrm{ng}$ of one of the DIG-UTP labelled riboprobes: hsc70 antisense or sense, hsp70 antisense or sense. Slides were rinsed in Tris / $\mathrm{NaCl}$ buffer $(500 \mathrm{mM} \mathrm{NaCl}, 1 \mathrm{mM}$ EDTA, $10 \mathrm{mM}$ Tris, $\mathrm{pH}$ 8.0), incubated for $30 \mathrm{~min}$ in RNase buffer (500 mM NaCl, $1 \mathrm{mM}$ EDTA, $10 \mathrm{mM}$ Tris, pH 7.5) containing $20 \mu \mathrm{g} / \mathrm{ml}$ RNase A, and washed for $1 \mathrm{~h}$ at $37^{\circ} \mathrm{C}$ in RNase buffer followed by $1 \mathrm{~h}$ wash at $70^{\circ} \mathrm{C}$ in $0.1 \times$ SSC. After post-hybridization washes, slides were rinsed in $2 \times \mathrm{SSC}$ and then incubated in blocking solution $(2 \times$ SSC, $6 \%$ fetal calf serum, $0.05 \%$ Triton X-100) for $1.5 \mathrm{~h}$ at room temperature. After blocking, slides were incubated with anti-digoxigenin-alkaline phosphatase
(1:500) in blocking solution for $24-36 \mathrm{~h}$ at $4^{\circ} \mathrm{C}$. Sections were washed 3 times for $30 \mathrm{~min}$ in buffer A (100 mM Tris, $\mathrm{pH} 8.0,100 \mathrm{mM} \mathrm{NaCl}), 5 \mathrm{~min}$ in AP buffer (100 mM Tris, pH 9.5, $100 \mathrm{mM} \mathrm{NaCl}, 50 \mathrm{mM} \mathrm{MgCl}_{2}, 0.1 \%$ Tween 20), and $5 \mathrm{~min}$ in AP buffer with $5 \mathrm{mM}$ levamisole. Slides were incubated in NBT/BCIP color reagent in AP buffer with 5 $\mathrm{mM}$ levamisole for 4-6 h. Slides were rinsed in buffer A to halt the color reaction, rinsed in water, counterstained with $0.5 \%$ neutral red, rinsed in water, dehydrated in $70 \%$ alcohol, air dried, and mounted in $50 \%$ permount $/ 50 \%$ xylene.

\subsection{In situ hybridization / cytochemistry}

Cytochemical procedures were performed alone or in combination with the non-radioactive in situ hybridization procedure described above. In the latter, the following procedures preceded the alcohol/chloroform pretreatment described above for the non-radioactive in situ hybridization protocol.

\subsection{Anti-GFAP immunocytochemistry}

An immunoperoxidase procedure was utilized for GFAP staining of astrocytes. Tissue sections were post-fixed for 5 min in $4 \%$ formalin in PBS, hydrated in buffer $\mathrm{C}(1 \times \mathrm{PBS}$, $0.1 \%$ bovine serum albumin, $0.2 \%$ Triton $\mathrm{X}-100)$ for 30 min, blocked in buffer $\mathrm{C}$ containing $1-2 \%$ horse serum, and incubated overnight at room temperature with primary antisera in buffer C, anti-GFAP, $0.125 \mu \mathrm{g} /$ slide. Slides were washed twice for $5 \mathrm{~min}$ in buffer $\mathrm{C}$, incubated for $1 \mathrm{~h}$ in buffer $\mathrm{C}$ containing secondary antibody, biotinylated anti-mouse $\mathrm{IgG}, 1: 1000$, washed twice for $5 \mathrm{~min}$ in buffer $\mathrm{C}$, incubated with Vectastain Elite $\mathrm{ABC}$ reagent for 30 min, washed for $10 \mathrm{~min}$ in buffer $\mathrm{C}$, and reacted for $5 \mathrm{~min}$ in DAB peroxidase substrate solution. Slides were washed in tap water for $5 \mathrm{~min}$, dehydrated through an alcohol series, cleared in xylene and mounted in $50 \%$ permount $/ 50 \%$ xylene.

\subsection{Lectin-cytochemistry}

For identification of microglia and oligodendrocytes lectin cytochemistry was employed. Microglia were detected using GSA $\mathrm{I}_{4} \mathrm{~B}_{4}$ from $G$. simplicifolia [50] and oligodendrocytes using GSL II from G. simplicifolia [51].

Fig. 3. and 4Time course induction of hsp70 mRNA in cortical layer 1 and the hippocampal fissure. Tissue sections were hybridized with a DIG-labelled hsp70 riboprobe and counterstained with neutral red. The presence of hsp70 mRNA was visualized as a blue precipitate in cortical layer 1 (A) and the hippocampal fissure (B). Glial cells were identified by their nuclear morphology. An induction of hsp70 mRNA was observed in glial cells (arrows) of hyperthermic animals (1, 2, 3, and 5 h). Hsp70 negative glial cells (arrowheads) were also observed. Bar $=8.75 \mu \mathrm{m}$.

Fig. 4. and 4Hsp70 mRNA expression in fiber tract regions following hyperthermia. Tissue sections were hybridized with a DIG-labelled hsp70 riboprobe and counterstained with neutral red. Expression of hsp70 mRNA (blue precipitate) was observed in glial cells (identified by their nuclear morphology) of the corpus callosum (A) and fimbria (B) following hyperthermia. Low magnification revealed the robust induction of hsp70 mRNA at 2 and $3 \mathrm{~h}$. Higher magnification (A,B $5 \mathrm{HR}$ ) showed that few cells expressed hsp70 mRNA at 5 h. 1,2,3 HR: bar $=22 \mu \mathrm{m}$; $5 \mathrm{HR}$ : bar $=8.75 \mu \mathrm{m}$. 


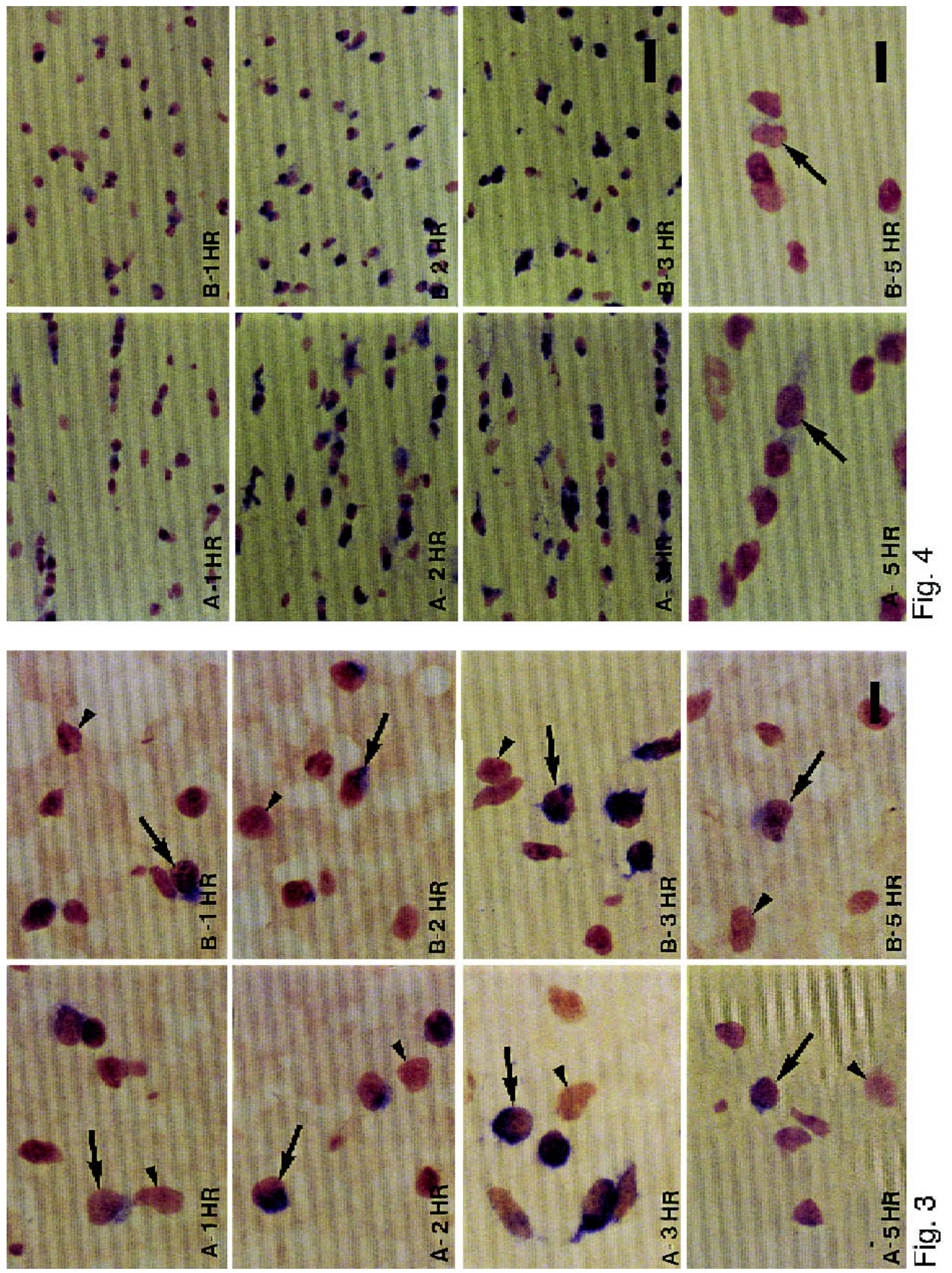


Tissue sections were fixed for $5 \mathrm{~min}$ in $4 \%$ formalin in PBS, hydrated in PBS with $0.1 \%$ Triton X-100 for 30 min and incubated with biotinylated lectin $\left(\mathrm{GSA} \mathrm{I}_{-} \mathrm{B}_{4}, 20\right.$ $\mu \mathrm{g} / \mathrm{ml}$; GSL II, $10 \mu \mathrm{g} / \mathrm{ml}$ ) for $2 \mathrm{~h}$ at room temperature. Slides were washed in PBS, twice for $5 \mathrm{~min}$. Slides incubated with the GSA I-B 4 lectin were then reacted for 5 min in DAB peroxidase substrate solution, washed for 5 min in tap water, dehydrated through an alcohol series, cleared in xylene and mounted in 50\% permount $/ 50 \%$ xylene. Slides incubated with the GSL II lectin were incubated with Vectastain Elite $\mathrm{ABC}$ reagent for $30 \mathrm{~min}$, washed for $10 \mathrm{~min}$ in buffer $\mathrm{C}$ and then reacted and processed as described above.

\section{Results}

\subsection{Time course analysis of constitutive hsc70 mRNA and stress-inducible hsp70 mRNA}

The kinetics of the transient increase in body temperature of rabbits is shown in Fig. 1. A maximal elevation of $2.6 \pm 0.06^{\circ} \mathrm{C}$ over the normal temperature of $39.6 \pm 0.03^{\circ} \mathrm{C}$ was attained at $1 \mathrm{~h}$ with a return to normal by $4 \mathrm{~h}$. In situ hybridization experiments (Fig. 2), using ${ }^{35} \mathrm{~S}$-labelled riboprobes, were carried out to examine cellular patterns of expression of constitutive hsc70 mRNA and stress-inducible hsp70 mRNA in the control (CON) and hyperthermic rabbit forebrain at $1,2,3,5$, and $10 \mathrm{~h}$. As seen in the left panels of Fig. 2, expression of hsc70 mRNA was detected in neuronal-enriched regions including cortical layers (CL), hippocampus (HP), and thalamus (THA). This regional pattern of hsc70 mRNA expression did not differ in control and hyperthermic treatments (compare left panels ACON with A-1 to A-10 HR).

As shown in the right panels of Fig. 2, hybridization with an ${ }^{35}$ S-labelled hsp70 riboprobe revealed a different pattern of expression in control compared to hyperthermic forebrain. Basal expression of hsp70 mRNA was detected in control cortical layers, hippocampus, and thalamus (Fig. 2B-CON). Following heat shock, a robust induction of hsp70 mRNA was apparent at 1,2 , and $3 \mathrm{~h}$ in fiber tract regions including the corpus callosum $(\mathrm{CC})$ and fimbria (F) (Fig. 2B-1 to B-3 HR). This induction of hsp70 mRNA was significantly reduced at $5 \mathrm{~h}$ (Fig. 2B-5 HR) and returned to control levels by $10 \mathrm{~h}$ (Fig. 2B-10 HR). We have shown that the hsp70 riboprobe detects a $2.7 \mathrm{~kb}$ mRNA in the rabbit brain and does not cross-hybridize to the constitutive $2.5 \mathrm{~kb}$ hsc70 mRNA which is detected specifically by the hsc70 riboprobe [13]. No signal was apparent in tissue sections hybridized with sense hsp70 or hsc70 riboprobes [13].

\subsection{Cellular localization of induced hsp70 mRNA by non-radioactive in situ hybridization}

Non-radioactive in situ hybridization was utilized to examine hsp70 mRNA expression in forebrain regions enriched in glial cell bodies, namely cortical layer 1, hippocampal fissure, corpus callosum, and fimbria. Fig. 3 shows the time course of hsp70 mRNA expression in cortical layer 1 (Fig. 3A) and the hippocampal fissure (Fig. $3 \mathrm{~B})$ at $1,2,3$, and $5 \mathrm{~h}$. The presence of hsp70 mRNA is visualized as a blue precipitate while cell nuclei are counterstained red. Glial cells were identified in these regions by their nuclear morphology. Hsp70 mRNA was not detected in all glial cells, as both hsp70 positive glial cells (arrows) and hsp70 negative glial cells (arrowheads) were observed. As shown in Fig. 4, an induction of hsp70 mRNA was also observed in glial cells of the corpus callosum (Fig. 4A) and fimbria (Fig. 4B). At higher magnification, it is apparent that by the $5 \mathrm{~h}$ time point only a few cells expressed hsp70 mRNA in both of these fiber tract regions (arrows, Fig. 4A,B 5 HR).

A quantitation of the percentage of hsp70 mRNA positive glial cells in the four regions of the forebrain is represented in Fig. 5. In all forebrain regions the most robust hsp70 mRNA induction was observed at 2 and $3 \mathrm{~h}$. Interestingly, in cortical layer 1 and in the hippocampal fissure, only $50 \%$ of the glial cells showed hsp70 mRNA expression while in the two fiber tract regions (corpus callosum and fimbria), $75 \%$ of the glial cells showed an induction of hsp70 mRNA by the $2 \mathrm{~h}$ time point.

\subsection{Composition of glial cell types in forebrain regions}

Fig. 6 shows the percentage contribution of astrocytes, microglia, and oligodendrocytes to the population of glial cells in the four selected regions of the rabbit forebrain. The predominant cell type in the two fiber tract regions (corpus callosum and fimbria) was the oligodendrocyte which comprised $69-70 \%$ of the total number of glial cells. In cortical layer 1 and the hippocampal fissure, oligodendrocytes comprised $27-32 \%$ of the glial cell population while $25-28 \%$ were astrocytes and $40-48 \%$ microglia.

\subsection{Identification of glial cell types expressing hsp70 $m R N A$}

To investigate the glial cell types inducing hsp70 mRNA in the various forebrain regions, a colocalization protocol consisting of both in situ hybridization and cytochemistry was employed. Anti-GFAP antibody was used as an astrocyte marker, while microglia and oligodendrocytes were identified using lectins from $G$. simplicifolia, GSA I-B ${ }_{4}$ [50] and GSL II [51], respectively. As previously shown, it is apparent that the most robust induction of hsp70 mRNA was observed in the corpus callosum and fimbria, as illustrated by ${ }^{35} \mathrm{~S}$-in situ hybridization (Fig. 2B), non-radioactive in situ hybridization (Figs. 3 and 4), and by cell counts of hsp70 mRNA positive glial cells (Fig. 5).

Fig. 7 shows the contribution of the three glial cell types to the expression of hsp70 mRNA in the corpus callosum (A-D) and fimbria $(\mathrm{E}-\mathrm{H})$ in $2 \mathrm{~h}$ hyperthermic animals. Tissue sections hybridized with a DIG-labelled 
hsp70 riboprobe and counterstained with neutral red revealed hsp70 mRNA positive (arrows) and negative (arrowheads) cells in both the corpus callosum (Fig. 7A) and the fimbria (Fig. 7E). In situ hybridization/cytochemistry of tissue sections using the hsp70 riboprobe and cell specific markers revealed hsp70 mRNA expression by microglia in both the corpus callosum (Fig. 7B) and the fimbria (Fig. 7F) as indicated by cells marked by arrows

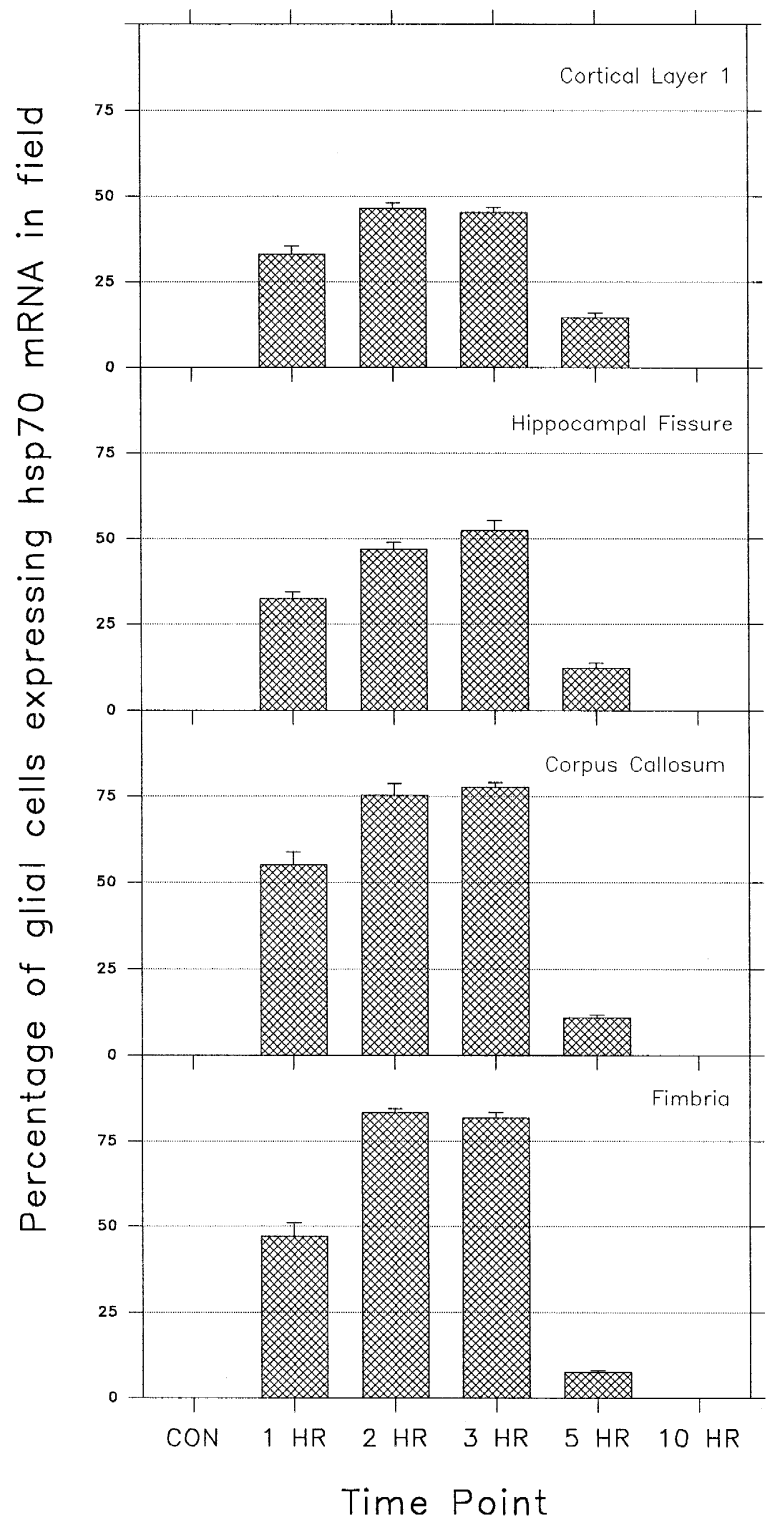

Fig. 5. Percentage of glial cells expressing hsp70 mRNA in forebrain regions. Cell counts were performed to determine the number of glial cells inducing hsp70 mRNA at different times following hyperthermia in four glial cell body-enriched regions. Glial cells were identified, as in Fig. 3Fig. 4, by their nuclear morphology following counterstaining with neutral red. The average number of glial cells in a field $(225 \mu \mathrm{m} \times 350$ $\mu \mathrm{m})$ was: cortical layer $1=40 \pm 1.6$ cells, hippocampal fissure $=50 \pm 2$ cells, corpus callosum $=84 \pm 3.8$ cells, and fimbria $=93 \pm 3.4$ cells. For each time point, 21 fields were counted in each of the four regions. Representative tissue sections from 3 animals per treatment $(1,2,3,5 \mathrm{~h})$ were analyzed. The maximal response was observed at 2 and $3 \mathrm{~h}$ in all four regions.

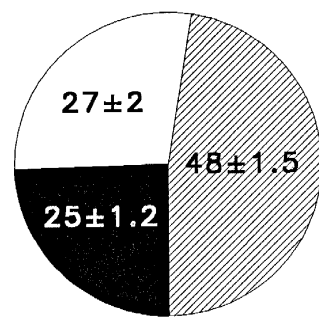

Cortical Layer 1

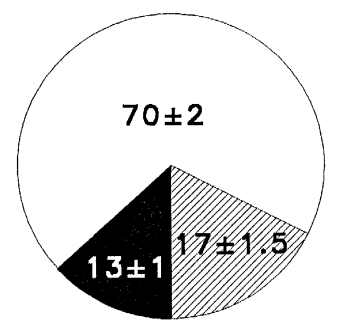

Corpus Callosum

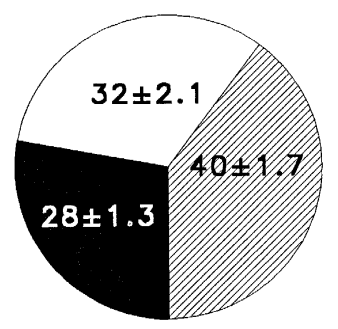

Hippocampal

Fissure

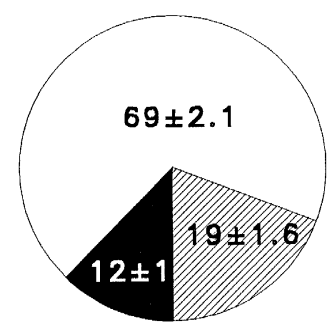

Fimbria

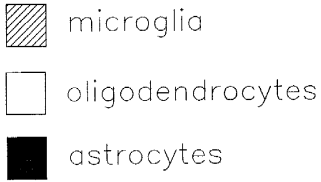

Fig. 6. Distribution of glial cell types in four regions of the rabbit forebrain. The percentage contribution of microglia, oligodendrocytes, and astrocytes to the glial cell population was determined in forebrain regions. The average number of glial cells in a field $(225 \mu \mathrm{m} \times 350 \mu \mathrm{m})$ was: cortical layer $1=48 \pm 1.8$ cells, hippocampal fissure $=57 \pm 2.4$ cells, corpus callosum $=96 \pm 3.3$ cells, and fimbria $=90 \pm 2.7$ cells. For each time point, 16 fields were counted in each of the four regions. Cell counts were performed on tissue sections (1) hybridized with a DIGlabelled proteolipid protein riboprobe and counterstained with neutral red, for oligodendrocytes, (2) reacted with the microglial lectin, GSA I-B and counterstained with cresyl violet, for microglia, and (3) immunoreacted with anti-GFAP antibody and counterstained with cresyl violet, for astrocytes. Data (mean \pm S.E.) are representative of 4 animals.

which were positive for hsp70 mRNA (blue precipitate) and the microglia-specific GSA I-B ${ }_{4}$ lectin (light brown). Similarly, oligodendrocytes also showed an induction of hsp70 mRNA in the corpus callosum (Fig. 7C) and fimbria (Fig. 7G) when GSL II lectin was used as the cell specific marker. The insets in Fig. 7 show a GSA I-B ${ }_{4}$ positive microglial cell (Fig. 7B) and a GSL II positive oligodendrocyte (Fig. 7C) from tissue sections that were processed for lectin cytochemistry alone. Induction of hsp70 mRNA by astrocytes was not detected in these two regions (Fig. $7 \mathrm{D}, \mathrm{H})$ when anti-GFAP antibody was used as the cell specific marker. As shown in Fig. 8, similar results were observed at $2 \mathrm{~h}$ in cortical layer 1 and the hippocampal fissure, that is, oligodendrocytes and microglia were observed to induce hsp70 mRNA (Fig. 8A,B, and D,E, respectively) while expression of hsp70 mRNA was not 

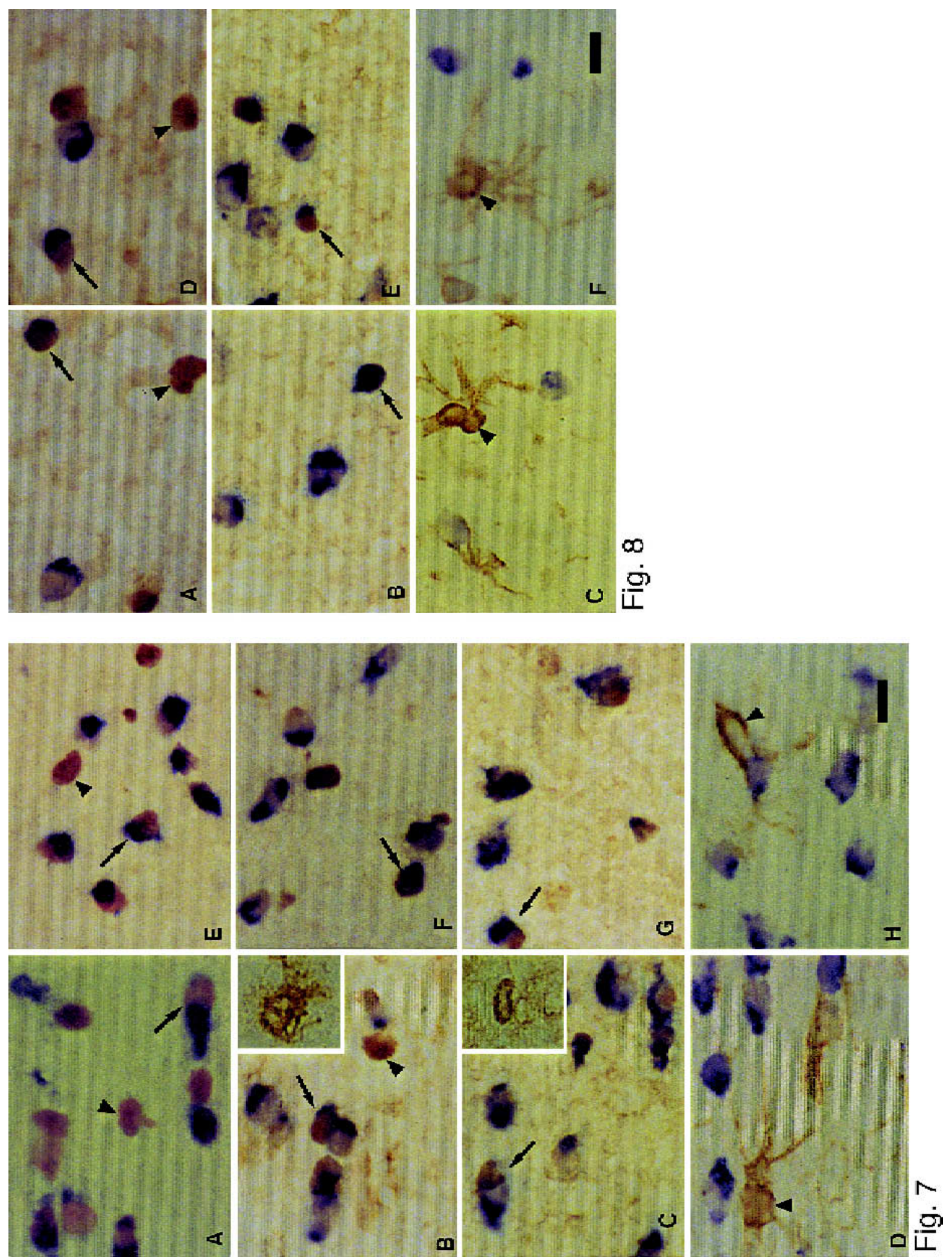

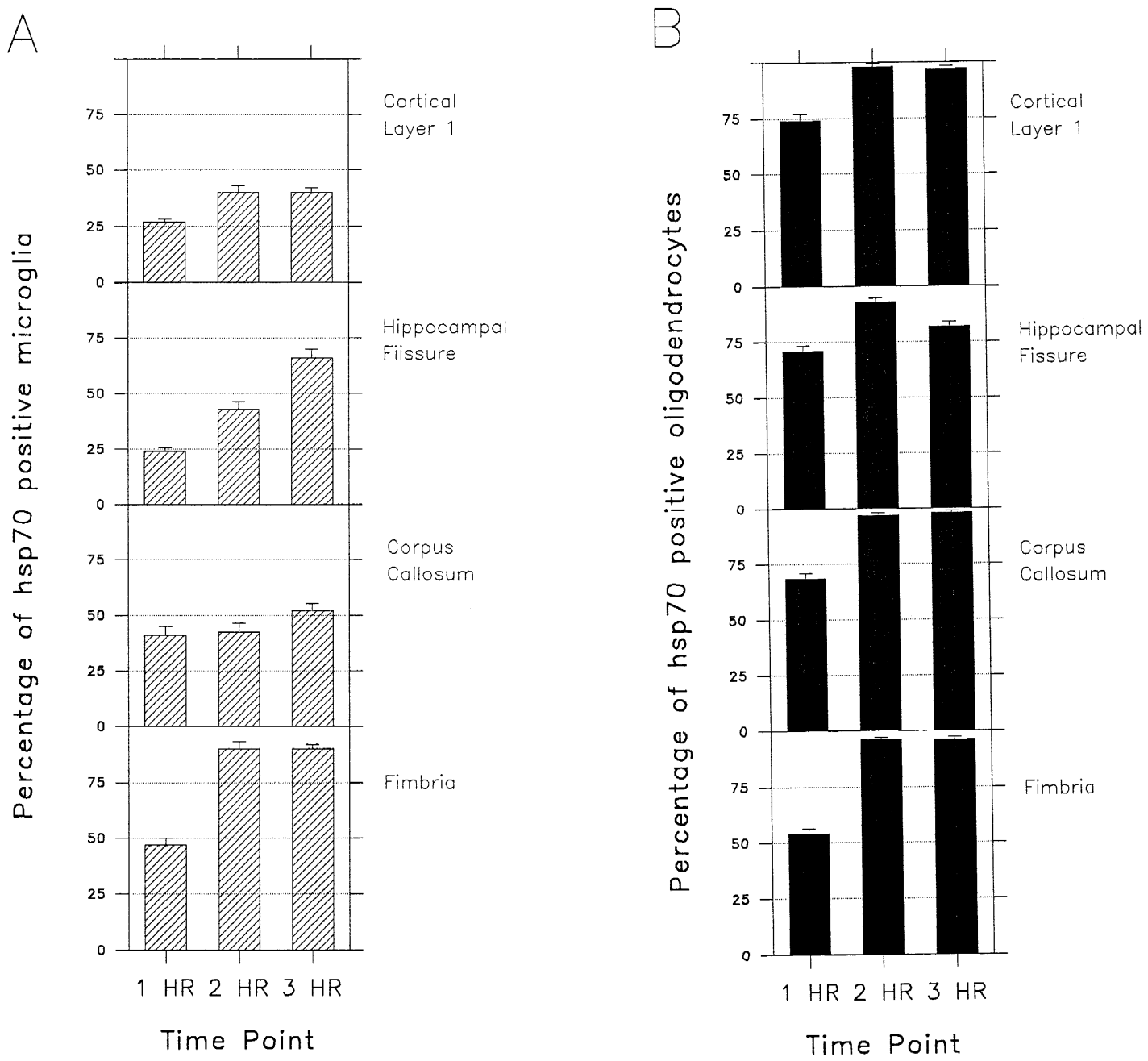

Fig. 9. Time course induction of hsp70 mRNA in microglia and oligodendrocytes. The percentage of hsp70 positive microglia (A) and oligodendrocytes (B) differed in the four regions examined at time points following hyperthermia. Data shown represent the percentage of microglia (GSA I-B ${ }_{4}$ positive) and the percentage of oligodendrocytes (GSL II positive) that were hsp70 positive. The average number of glial cells in a field ( $225 \mu \mathrm{m} \times 350 \mu \mathrm{m})$ were: cortical layer 1 : microglia $=16 \pm 0.8$ cells, oligodendrocytes $=15 \pm 0.7$ cells; hippocampal fissure: microglia $=19 \pm 1$ cells, oligodendrocytes $=15 \pm 0.9$ cells; corpus callosum: microglia $=20 \pm 1.8$ cells, oligodendrocytes $=82 \pm 2$ cells; and fimbria: microglia $=27 \pm 2$ cells, oligodendrocytes $=98 \pm 2$ cells. Hyperthermic time points are indicated in hours. Data are representative of 3 animals. For each time point, 15 fields were counted for each of the four regions.

observed in astrocytes (Fig. 8C,F). In the hippocampal fissure, where the highest percentage of astrocytes was found, in a field of 20 anti-GFAP positive astrocytes, none were observed to be hsp70 mRNA positive. Comparable results were observed in the other three regions.

These data demonstrate that microglia and oligodendro-

Fig. 7. Identification of glial cell types expressing hsp70 mRNA in fiber tract regions. Non-radioactive in situ hybridization revealed hsp70 positive (arrows) and hsp70 negative (arrowheads) glial cells in the corpus callosum (A) and fimbria (E) in $2 \mathrm{~h}$ hyperthermic animals. Dual in situ hybridization/cytochemistry with cell type markers, lectins GSA I-B ${ }_{4}$ for microglia (B, F), GSL II for oligodendrocytes (C, G), and anti-GFAP for astrocytes (D, H), showed hsp70 positive microglia (arrows; B, corpus callosum; F, fimbria), hsp70 positive oligodendrocytes (arrows; C, corpus callosum; G, fimbria), and hsp70 negative astrocytes (arrowheads; D, corpus callosum; H, fimbria) in fiber tract regions. Hsp70 negative microglia were observed in

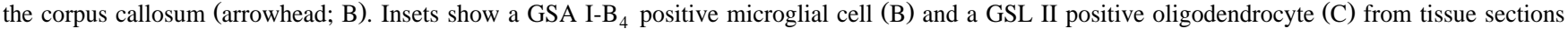
that were processed by lectin cytochemistry alone. Bar $=8.75 \mu \mathrm{m}$.

Fig. 8. In situ hybridization/cytochemistry with cell type markers in cortical layer 1 and the hippocampal fissure. Cell type markers were used to identify glial cells expressing hsp70 mRNA in $2 \mathrm{~h}$ hyperthermic animals, lectins GSA I-B 4 for microglia (A, D), GSL II for oligodendrocytes (B, E), and anti-GFAP antibody for astrocytes (C, F). Hsp70 positive microglia (arrows, A, D) and hsp70 positive oligodendrocytes (arrows, B, E) were observed in cortical layer 1 (A, B) and the hippocampal fissure (D, E). Hsp70 mRNA was not detected in astrocytes (arrowheads; C, cortical layer 1; F, hippocampal fissure). Hsp70 negative microglia were also observed (arrowheads, A, D). Bar $=8.75 \mu \mathrm{m}$. 
cytes are the cell types contributing to the glial induction of hsp70 mRNA observed in four selected regions of the forebrain of hyperthermic rabbits. Do all microglia or all oligodendrocytes respond to hyperthermia by inducing hsp70 mRNA? Cell counts were performed to determine the percentage of hsp70 positive microglia and oligodendrocytes at the 1,2 , and $3 \mathrm{~h}$ time points. Results are presented in Fig. 9A for microglia and in Fig. 9B for oligodendrocytes. These data show that populations of microglial cells react differently to hyperthermia in the four forebrain regions while oligodendrocytes respond similarly in these regions. That is, a maximal response was observed in microglia of the fimbria, where $90 \%$ of microglia were observed to be hsp70 mRNA positive at $2 \mathrm{~h}$, while less than $50 \%$ of microglia in cortical layer 1 were observed to induce hsp70 mRNA. Hsp70 negative microglial cells (arrowheads) were observed in cortical layer 1 (Fig. 8A), the hippocampal fissure (Fig. 8D), and the corpus callosum (Fig. 7B) at the $2 \mathrm{~h}$ time point. In comparison, almost all oligodendrocytes (95-98\%) induced hsp70 mRNA by $2 \mathrm{~h}$ in the four regions examined.

\section{Discussion}

The time course of expression of constitutive hsc70 mRNA and stress-inducible hsp70 mRNA following a physiologically relevant increase in body temperature $\left(2.6^{\circ} \mathrm{C}\right)$ was examined using radioactive in situ hybridization. Both hsc70 mRNA and basal hsp70 mRNA were localized to neuron-enriched regions of the forebrain in unstressed rabbits. Following hyperthermia $(1,2,3,5$, and $10 \mathrm{~h}$ ), the cellular pattern of expression of hsc70 mRNA did not change, while the hsp70 mRNA species was strongly induced, particularly in fiber tract regions including the corpus callosum and fimbria.

Non-radioactive in situ hybridization was subsequently used to investigate hsp70 mRNA expression following hyperthermia in glial cell body-enriched regions of the rabbit forebrain. In the four regions examined, cortical layer 1, hippocampal fissure, corpus callosum, and fimbria, a strong glial induction of hsp70 mRNA was observed at 1,2 , and $3 \mathrm{~h}$. At $5 \mathrm{~h}$, few cells expressed hsp70 mRNA in these glial cell body-enriched regions and at $10 \mathrm{~h}$, expression of hsp70 mRNA was not detected. Quantitation of the number of hsp70 mRNA positive glial cells revealed that the most robust induction was observed at 2 and $3 \mathrm{~h}$. To identify the glial cell types expressing hsp70 mRNA, cytochemistry was first performed with cell type markers (anti-GFAP for astrocytes, lectin GSA I-B ${ }_{4}$ for microglia, lectin GSL II for oligodendrocytes) and subsequently, tissue sections were hybridized with a DIG-labelled hsp70 riboprobe. This colocalization analysis revealed that oligodendrocytes and microglia induced hsp70 mRNA in cortical layer 1, hippocampal fissure, corpus callosum and fimbria, while an induction of hsp70 mRNA was not detected in astrocytes in these forebrain regions.
An induction of hsp70 mRNA in oligodendrocytes and in microglia following hyperthermia is consistent with previous reports. Work in our laboratory has demonstrated an induction of hsp70 mRNA in oligodendrocytes in fiber tracts of the cerebellum, brain stem, and spinal cord [13,26-28]. In tissue culture studies, an induction of hsp70 protein in oligodendrocytes has been reported in rat [33], mouse [43] and human [10,14]. In addition, an induction of hsp70 protein has been reported in human microglial cells following hyperthermia $[10,14]$.

Microglia have also been shown to induce hsp70 protein in response to focal ischemia in rat brain [47], although the percentage of microglia responding to ischemia (5-8\%) was much less than observed in response to hyperthermia. Soriano et al. [47] described microglia inducing hsp70 as stellate microglia. The morphology shown is comparable to the reported morphology for ramified microglia [11]. In the present study, tissue sections processed with the microglia lectin alone, revealed a staining pattern comparable to ramified microglia (see inset in Fig. 7). Therefore, it appears that in response to both hyperthermia and ischemia [47], ramified microglia induce hsp70.

With respect to astrocytes, in vitro analysis of hsp70 mRNA and protein following hyperthermia has yielded variable results in the literature. Studies with cultured forebrain astrocytes of the rat have reported an induction hsp70 mRNA following hyperthermic treatment of $45^{\circ} \mathrm{C}$ for $20 \mathrm{~min}$ [32,33]. In the present study, forebrain regions of the rabbit were examined and hsp70 mRNA was not detected in GFAP positive astrocytes. This apparent discrepancy may result from differences in the degree of the hyperthermic insult. A supraphysiological increase of $8^{\circ} \mathrm{C}$ was used in the tissue culture experiments [32,33]. This is far greater than the whole body temperature increase $\left(2.6^{\circ} \mathrm{C}\right)$ which was employed in the present study.

Consistent with our observations, human adult astrocytes did not show an induction of hsp70 protein following hyperthermia at $43^{\circ} \mathrm{C}$ for $90 \mathrm{~min}[10,14]$. An induction of hsp70 protein in astrocytes has been reported for human fetal [42] and mouse [43] tissue, although the response by astrocytes was attenuated in these systems in comparison to a strong hsp70 induction in oligodendrocytes $[42,43]$. Also the brain region which was analyzed was not specified. Investigations in our laboratory has revealed hsp70 mRNA induction in Bergmann glia, a specialized astrocyte, in the rabbit cerebellum [26] which is consistent with the reported induction of hsp70 mRNA and protein in cultured cerebellar astrocytes [30]. In glia-enriched regions of the rabbit forebrain, the present investigation revealed hsp70 mRNA induction in oligodendrocytes and microglia.

An induction of hsp70 in neurons following other neural traumas, including global ischemia $[7,34,35,45,54]$ and kainic acid induced seizures [53], has been reported. These studies demonstrate that neurons are capable of mounting a heat shock response, and yet, in response to a fever-like hyperthermia a rapid, transient induction of hsp70 mRNA 
was observed in glial cells, not neurons. Perhaps, this level of hyperthermia is not a severe enough trauma to trigger an induction of hsp70 mRNA in neurons. In addition, neurons showed high expression of constitutive hsc70 mRNA and protein which may confer protection to this level of hyperthermia [28]. Astrocytes have also been reported to induce hsp70 protein after focal ischemia [44]. Therefore, like neurons, this neural cell type is capable of mounting a heat shock response and yet in our physiologically relevant hyperthermia model, no comparable induction was observed. Therefore, neurons and astrocytes may require a more severe stress, such as ischemia, before inducing hsp70.

Within the forebrain, regional differences in the hsp70 mRNA induction in response to hyperthermia were observed for microglia and oligodendrocytes. By $2 \mathrm{~h}, 95-98 \%$ of oligodendrocytes in the four glia-enriched regions induced hsp70 mRNA. This response by oligodendrocytes may reflect the sensitivity of this glial cell type to fever-like temperature elevations. In comparison, a maximal induction of hsp70 mRNA in microglia was observed only in the fimbria where $90 \%$ were hsp70 positive at $2 \mathrm{~h}$. Less than $50 \%$ of the microglia were hsp70 positive in cortical layers, hippocampal fissure, and corpus callosum at the same time point. The observed cell type variance in the response to hyperthermia may be due to differences in the in vivo threshold temperature for activation of the heat shock response in the three glial cell types. On the other hand, differences in the mechanisms of induction may exist in various neural cell types [29]. In the present experiments, a $2.6^{\circ} \mathrm{C}$ increase in temperature exceeds the activation threshold of oligodendrocytes, triggers the induction of hsp70 mRNA in a subpopulation of microglial cells, and is below the induction threshold of forebrain astrocytes. Clearly, a differential induction of heat shock mRNA is apparent in glial cell types in the rabbit forebrain following a physiologically relevant increase in body temperature.

\section{Acknowledgements}

These studies were supported by grants from MRC Canada to I.R.B.

\section{References}

[1] Angelidis, C.E., Lazaridis, I. and Pagoulatos, G.N., Constitutive expression of heat-shock protein 70 in mammalian cells confers thermoresistance, FEBS Lett., 199 (1991) 35-39.

[2] Barbe, M.F., Tytell, M., Gower, D.J. and Welch, W.J., Hyperthermia protects against light damage in the rat retina, Science, 241 (1988) 1817-1820.

[3] Becker, J. and Craig, E.A., Heat-shock proteins as molecular chaperones, Eur. J. Biochem., 219 (1994) 11-23.

[4] Brown, I.R., Induction of heat shock (stress) genes in the mammalian brain by hyperthermia and other traumatic events: a current perspective, J. Neurosci. Res., 27 (1990) 247-255.
[5] Brown, I.R., Induction of heat shock genes in the mammalian brain by hyperthermia and tissue injury. In R.J. Mayer and I.R. Brown (Eds.), Heat Shock Proteins in the Nervous System, Academic Press, London, 1994, pp. 31-53.

[6] Chopp, M., Chen, H., Ho, K.L., Dereski, M.O., Brown, E., Hetzel, F.W. and Welch, K.M.A., Transient hyperthermia protects against subsequent forebrain ischemic damage in the rat, Neurology, 39 (1989) 1396-1398.

[7] Chopp, M., Li, Y., Lin, A., Huang, L.E. and Liu, A.Y.-C., Neuronal injury and expression of $72-\mathrm{kDa}$ heat shock protein after focal forebrain ischemia, Acta Neuropathol., 83 (1991) 66-71.

[8] Cosgrove, J.W. and Brown, I.R., Heat shock protein in the mammalian brain and other organs following a physiologically relevant increase in body temperature induced by LSD, Proc. Natl. Acad. Sci. USA, 80 (1983) 569-573.

[9] Craig, E.A., Essential roles of $70 \mathrm{kDa}$ heat inducible proteins, BioEssays, 11 (1989) 48-52.

[10] D'Souza, S., Antel, J.P. and Freedman, M.S., Cytokine induction of heat shock protein expression in human oligodendrocytes: an interleukin-1-mediated mechanism, J. Neuroimmunol., 50 (1994) 17-24.

[11] Davis, E.J., Foster, T.D. and Thomas, W.E., Cellular forms and functions of brain microglia, Brain Res. Bull., 34 (1994) 73-78.

[12] Foster, J.A. and Brown, I.R., Basal expression of stress-inducible hsp70 mRNA detected in hippocampal and cortical neurons of normal rabbit brain, Brain Res., 724 (1996) 73-83.

[13] Foster, J.A., Rush, S.J. and Brown, I.R., Localization of constitutive and hyperthermia-inducible heat shock mRNAs (hsc70 and hsp70) in the rabbit cerebellum and brain stem by non-radioactive in situ hybridization, J. Neurosci. Res., 41 (1995) 603-612.

[14] Freedman, M.S., Buu, N.N., Ruijs, T.C.J., Williams, K. and Antel, J.P., Differential expression of heat shock proteins by human glial cells, J. Neuroimmunol., 41 (1992) 231-238.

[15] Georgopoulos, C. and Welch, W.J., Role of the major heat shock proteins as molecular chaperones, Annu. Rev. Cell Biol., 9 (1993) 601-634.

[16] Gething, M.-J. and Sambrook, J., Protein folding in the cell, Nature, 355 (1992) 33-45.

[17] Hartl, F.-U., Hlodan, R. and Langer, T., Molecular chaperones in protein folding: the art of avoiding sticky situations, Trends Biochem. Sci., 19 (1994) 20-25.

[18] Johnston, R.N. and Kucey, B.L., Competitive inhibition of hsp70 gene expression causes thermosensitivity, Science, 242 (1988) $1551-1554$.

[19] Khan, N.S. and Sotelo, J., Heat shock stress is deleterious to CNS cultured neurons microinjected with anti-HSP70 antibodies, Biol. Cell, 65 (1989) 199-202.

[20] Kinouchi, H., Sharp, F.R., Koistinaho, J., Hicks, K., Kamii, H. and Chan, P.H., Induction of heat shock hsp70 mRNA and HSP70 protein in neurons in the 'penumbra' following focal cerebral ischemia in the rat, Brain Res., 619 (1993) 334-338.

[21] Koroshetz, W.J. and Bonventre, J.V., Heat shock response in the central nervous system, Experientia, 50 (1994) 1085-1091.

[22] Li, G.C., Ligeng, L., Liu, Y.-K., Mak, J.Y., Chen, L. and Lee, W.M.F., Thermal response of rat fibroblasts stably transfected with the human 70-kDa heat shock protein-encoding gene, Proc. Natl. Acad. Sci. USA, 88 (1991) 1681-1685.

[23] Lindquist, S. and Craig, E.A., The heat shock proteins, Annu. Rev. Genet., 22 (1988) 631-677.

[24] Lowenstein, D.H., Chan, P.H. and Miles, M.F., The stress protein response in cultured neurons: Characterization and evidence for a protective role in excitotoxicity, Neuron, 7 (1991) 1053-1060.

[25] Manzerra, P. and Brown, I.R., Time course induction of a heat shock gene (hsp70) in the rabbit cerebellum after LSD in vivo: involvement of drug-induced hyperthermia, Neurochem. Res., 15 (1990) 53-59.

[26] Manzerra, P. and Brown, I.R., Distribution of constitutive- and hyperthermia-inducible heat shock mRNA species (hsp70) in the 
Purkinje layer of the rabbit cerebellum, Neurochem. Res., 17 (1992) 559-564.

[27] Manzerra, P. and Brown, I.R., Expression of heat shock genes (hsp70) in the rabbit spinal cord: localization of constitutive and hyperthermia-inducible mRNA species, J. Neurosci. Res., 31 (1992) 606-615.

[28] Manzerra, P., Rush, S.J. and Brown, I.R., Temporal and spatial distribution of heat shock mRNA and protein (hsp70) in the rabbit cerebellum in response to hyperthermia, J. Neurosci. Res., 36 (1993) 480-490.

[29] Marcuccilli, C.J., Mathur, S.K., Morimoto, R.I., and Miller, R.J., Regulatory differences in the stress response of hippocampal neurons and glial cells after heat shock, J. Neurosci., 16 (1996) 478-485.

[30] Marini, A.M., Kozuka, M., Lipsky, R.H. and Nowak, T.S., 70-Kilodalton heat shock protein induction in cerebellar astrocytes and cerebellar granule cells in vitro: Comparison with immunocytochemical localization after hyperthermia in vivo, J. Neurochem., 54 (1990) 1509-1516.

[31] Morrison-Bogorad, M., Pardue, S., McIntire, D.D. and Miller, E.K., Cell size and the heat-shock response in rat brain, J. Neurochem., 63 (1994) 857-867.

[32] Nishimura, R.N., Dwyer, B.E., de Vellis, J. and Clegg, K.B., Characterization of the major $68 \mathrm{kDa}$ heat shock protein in a rat transformed astroglial cell line, Mol. Brain Res., 12 (1992) 203-208.

[33] Nishimura, R.N., Dwyer, B.E., Welch, W., Cole, R., de Vellis, J. and Liotta, K., The induction of the major heat-stress protein in purified rat glial cells, J. Neurosci. Res., 20 (1988) 12-18.

[34] Nowak, T.S., Ikeda, J. and Nakajima, T., 70 kilodalton heat shock protein and c-fos gene expression following transient ischemia, Stroke, 21 (Suppl. III) (1990) 107-111.

[35] Nowak, T.S., Localization of $70 \mathrm{kDa}$ stress protein mRNA induction in gerbil brain after ischemia, J. Cereb. Blood Flow Metab., 11 (1991) 432-439.

[36] Nowak, T.S., Suga, S. and Saito, N., The heat shock response and gene expression in brain after ischemia. In R.J. Mayer and I.R. Brown (Eds.), Heat Shock Proteins in the Nervous System, Academic Press, London, 1994, pp. 55-81.

[37] Pelham, H., Heat shock proteins: coming in from the cold, Nature, 332 (1988) 776-777.

[38] Pelham, H.R.B., Speculations of the functions of the major heat shock and glucose-regulated proteins, Cell, 46 (1986) 959-961.

[39] Peterson, S.L. and McCrone, S., Characterization of the receptor complement of individual neurons using dual-label in situ hybridization histochemistry. In J.H. Eberwine, K.L. Valentino and J.D. Barchas (Eds.), In Situ Hybridization in Neurobiology: Advances in Methodology, Oxford University Press, New York, 1994, pp. 78-95.

[40] Riabowol, K.T., Mizzen, L.A. and Welch, W.J., Heat shock is lethal to fibroblasts microinjected with antibodies against hsp70, Science, 242 (1988) 433-436.

[41] Rordorf, G., Koroshetz, W.J. and Bonventre, J.V., Heat shock protects cultured neurons from glutamate toxicity, Neuron, 7 (1991) 1043-1051.

[42] Satoh, J. and Kim, S.U., Hsp72 induction by heat stress in human neurons and glial cells in culture, Brain Res., 653 (1994) 243-250.

[43] Satoh, J., Yamamura, T., Kunishita, T. and Tabira, T., Heterogeneous induction of $72-\mathrm{kDa}$ heat shock protein (hsp72) in cultured mouse oligodendrocytes and astrocytes, Brain Res., 573 (1992) $37-43$.

[44] Sharp, F.R., Lowenstein, D., Simon, R.P. and Hisanaga, K., Heat shock protein hsp70 induction in cortical and striatal astrocytes and neurons following infarction, J. Cereb. Blood Flow Metab., 11 (1991) 621-627.

[45] Simon, R.P., Cho, H., Gwinn, R. and Lowenstein, D.H., The temporal profile of $72-\mathrm{kDa}$ heat shock protein expression following global ischemia, J. Neurosci., 11 (1991) 881-889.

[46] Sorger, P.K. and Pelham, H.R.B., Cloning and expression of a gene encoding hsc73, the major hsp70-like protein in unstressed cells, EMBO J., 6 (1987) 993-998.

[47] Soriano, M.A., Planas, A.M., Rodriguez-Farre, E. and Ferrer, I., Early $72-\mathrm{kDa}$ heat shock protein induction in microglial cells following focal ischemia in the rat brain, Neurosci. Lett., 182 (1994) 205-207.

[48] Sprang, G.K. and Brown, I.R., Selective induction of a heat shock gene in the fibre tracts and cerebellar neurons of the rabbit brain, Mol. Brain Res., 3 (1987) 89-93.

[49] Stege, G.J.J., Brunsting, J.F., Kampinga, H.H. and Konings, A.W.T., Thermotolerance and nuclear protein aggregation: protection against initial damage or better recovery, J. Cell. Physiol., 164 (1995) $579-586$.

[50] Streit, W.J., An improved staining method for rat microglial cells using the lectin from Griffonia simplicifolia (GSA I-B4), J. Histochem. Cytochem., 38 (1990) 1683-1686.

[51] Supler, M.L., Semple-Bowland, S.L. and Streit, W.J., Oligodendrocytes produce low molecular weight glycoproteins containing $\mathrm{N}$ acetyl-D-glucosamine in their Golgi apparatus, Glia, 10 (1994) 193201.

[52] Uney, J.B., Kew, J.N.C., Staley, K., Tyers, P. and Sofroniew, M.V., Transfection-mediated expression of human Hsp70i protects rat dorsal root ganglion neurones and glia from severe heat stress, FEBS Lett., 334 (1993) 313-316.

[53] Vass, K., Berger, M.L., Nowak, T.S. and Welch, W.J., Induction of stress protein HSP70 in nerve cells after status epilepticus in the rat, Neurosci. Lett., 100 (1989) 259-264.

[54] Vass, K., Welch, W.J. and Nowak, T.S., Localization of stress protein HSP70 in gerbil brain after ischemia, Acta Neuropathol., 77 (1988) 128-135.

[55] Watowich, S.S. and Morimoto, R.I., Complex regulation of heat shock- and glucose-responsive genes in human cells, Mol. Cell. Biol., 8 (1988) 393-405.

[56] Welch, W.J., Mammalian stress response: Cell physiology, structure/function of stress proteins, and implications for medicine and disease, Physiol. Rev., 72 (1992) 1063-1081.

[57] Welch, W.J., Heat shock protein functioning as molecular chaperones: their roles in normal and stressed cells, Phil. Trans. R. Soc. Lond., 339 (1993) 327-333.

[58] Welsh, F.A., Moyer, D.J. and Harris, V., Regional expression of heat shock protein-70 mRNA and c-fos mRNA following focal ischemia in rat brain, J. Cereb. Blood Flow Metab., 12 (1992) 204-212.

[59] Wu, B., Hunt, C. and Morimoto, R.I., Structure and expression of the human gene encoding major heat shock protein hsp70, Mol. Cell. Biol., 5 (1985) 330-341. 